\title{
Syria: \\ Evaluation of Russo-American Zero-Sum Game in the Protracted Fratricide
}

\author{
Uchenna SIMEON
}

\begin{abstract}
This research examines the part played by the United States and Russia in the prolonged catastrophe in Syria. Syria (a strategic ally of Russia) has been enveloped by civil hostilities since 2011. Inspired by the 'Arab Spring' that swept through the region in 2011, what started as a fundamental challenge and strong opposition to Bashir al-Assad's over-lordship has exploded into a full blown internal warfare, pitting government forces and their foreign allies led by Russia against a range of anti-government rebels and their overseas sponsors spearheaded by the United States. As the war rages on, the role being played by the two key external forces (US and Russia) has come under serious scrutiny. Pulling from qualitative data collected through secondary sources, this paper argues that the supremacy struggle between US and Russia has contributed in exacerbating rather than ameliorating the situation. The study recommends that there is every and urgent need for the Syrian people themselves especially the leadership to look inwards with a view to finding a lasting solution to the unrest as continued reliance on external forces will spell doom to the prospects of peace in Syria.
\end{abstract}

Keywords: Arab Spring, civil hostilities, Russia, Syria, United States.

\author{
Uchenna SIMEON \\ Department of Political Science \\ Faculty of Social Sciences \\ Federal University Lafia \\ Nasarawa State, Nigeria \\ E-mail: uchesim@yahoo.com \\ Conflict Studies Quarterly \\ Issue 21, October 2017, pp. 101-122
}

DOI:10.24193/csq.21.5

Published First Online: 10/03/2017

\section{Introduction}

"Conflict ... is a theme that has occupied the thinking of man more than any other, save only God and love". (Rapoport, n.d., as cited in Simeon, 2001, p. 2).

"Every war has two faces. It is a conflict both between and within political systems; a conflict that is both external and internal. It is undeniable that internal wars affect the international system and that the international system affects internal wars". (Modelski, 1964 as cited in Kegley, 2007, p.428).

Reminiscent of the 'Hobbesian Anomie' that characterized the 'State of Nature', the 
Middle East, more than any other region of the world, has been the scene of ferocious strife both between and within political systems. For over half a century now, this region has remained very notorious in terms of regional cataclysms. As empirical and historical facts so obviously confirmed, the region has experienced about 40 wars since the late $19^{\text {th }}$ Century. If it is not between Israel and its Arab neighbours, it is between two Arab countries like the one between Iraq and Iran that lasted for 8 years (1980-1988). In some other cases, it may arise from foreign intervention, like the United States led 'Operation Desert Storm' against Iraq following the latter's invasion of its Arab neighbour, Kuwait on August 2, 1990. The frequency at which violent transactions have gained ascendancy over the pursuit of peaceful settlement of disputes in the Middle East is alarming. 'Torn by Strife', 'Volatile Middle East' and 'the Middle East Zone of Turmoil', to mention just a few, are some of the phrases analysts have employed to express the rage in this part of the globe.

As if not yet satisfied with the rate of recurrence of wanton destruction of lives and properties, in recent times, Syria, one of the Middle East States (a strategic ally of former USSR, now Russia) and an arc adversary to Israel (US key partner in the Middle East), has been engulfed in a civil war that has lasted for about six (6) years now. What started as a deep-seated challenge and sturdy resistance to Bashar al-Assad's autocratic rule has metamorphosed into a full blown civil hostilities following bloody crackdown on protesters with the government troops on one side and an array of rebels represented by Syrian National Coalition on the other side engaged in fierce battle over the control of the territory and government of the Syrian state.

Syrian crisis has caused what is today regarded as the world's largest humanitarian and security disaster, with estimated 13.5 million people in need of humanitarian assistance, 6.3 million are internally displaced, about 11 million are on the run, 5.5 million children affected by the crisis, 7.6 million Internally Displaced Persons (IDPs), 4.8 million have become refugees in the following countries: Turkey - 2,764,500, Iraq, 228,894, Lebanon, about 1,017,433 with one in every four person coming from Syria while in Jordan with a total of about 655,404, one in every 10 people comes from Syria (Unocha, 2016 as cited in Mercy Corps, 2017) while in Egypt and North Africa, they are about 150,258 (European Commission, 2017b).

According to Stephen 0'Brien, the UN Under-Secretary-General for Humanitarian Affairs and Emergency Relief Coordinator, in Syria, close to 7 million children live in poverty, about 1.75 million are out of school children, 1.35 million are at the risk of dropping out while 7,400 schools have either been destroyed or made inaccessible ( 0 'Brien, 2017). The foregoing situation has created an urgent need for humanitarian assistance as according to UN report, while $\$ 4.5$ billion is required to cater for the needs of the displaced and vulnerable persons in Syria in 2016, however, only $\$ 2,9$ billion was realized (UN as cited in Mercy Corps, 2017). The economy is not left out too. Based on 
World Bank Report, within the first four years of the conflict, 538,000 jobs were lost as the unemployment rate among the youths stood at 78 percent in addition to loss in the Gross Domestic Product (GDP) to the tune of US $\$ 226$ billion or four times the year 2010 figure (World Bank, 2017). As reported by Euro News (2017), the extent of the damage done to the economy is such that even if Syrian crisis ends today, it will take between 10 to 15 years for the country's per capita GDP to return to pre-conflict levels as the total economic losses so far are estimated at around 255 billion Euros.

Suffice it to state that throughout history, individuals and groups have in one form or another resorted to violence or its potential use as a tactic of political action as when violence is deployed by groups in search of power, by groups holding power and by groups in the process of losing the same power; in the defence of order by the privileged, the name of justice by the subjugated and in fear of dislocation by the threatened (Agi, 1998); nevertheless, its prevalence in the political life of Syrians has necessitated a critical examination if we must overcome the temptation of locating the Syrian debacle exclusively on domestic conditions.

It is in the light of this that this study sets out to assess the role of the United States and Russia in the persistent Syrian stalemate.

\section{Background to the Syrian Catastrophe}

The Syrian Arab Republic, one of the Middle East countries, is located along the eastern shore of the Mediterranean sea covering a land area of 183,630 square kilometres (sq km) and 1,550 sq km of water, giving a total area of 185,180 sq km, including the Golan heights region of 1,176 sq km which was captured and annexed by Israel in 1967 and December 14, 1981, respectively, making it the $89^{\text {th }}$ largest country in the world (Worldmark Encyclopedia of Nations, 2007; Worldatlas, 2015). Syria gain its independence from Turkey in 1946 and with a land boundary length of 2,253 km and a coastline of $193 \mathrm{~km}$, it shares boundaries with Turkey to the North, Iraq to the East and Southeast, Jordan to the South, Israel to the Southwest and Lebanon as well as Mediterranean sea to the West (Worldmark Encyclopedia of Nations, 2007). Approximating several other countries in the Middle East, the Syrian population comprises diverse ethnic and religious groups. Roughly 90 per cent of the entire population are ethnic Arabs; however, there are small ethnic minorities, remarkably Kurds, which happens to the country's leading distinct ethnic/linguistic minority constituting between 7-10 per cent of the total population (Sharp \& Blanchard, 2013).

Of more importance in Syria are religious sectarian diversities because, besides the majority Sunni Muslims that represent over 70 per cent of Syrian population, there exist numerous religious sectarian minorities, including three smaller Muslim sects of Alawite (12 per cent), Druze (3 per cent) and Ismailis (2\%) and a number of Christian denominations, such as Greek Orthodox Christian (9\%), American-Christian, Assyrian 
Christian which alongside minority groups like Turkmen-Sunni, Circassian-Sunni and others constitute 1\% of the population (Sharp \& Blanchard, 2013; Holliday, 2011). Despite the secular nature of the ruling Baath party, religious sects have, however, been important to some Syrians as symbols of group identity and determination of political action as can be attested to by the Assad led Baath party's cultivation of Alawites as not only the key base of support but also the dominant group in the composition of the elite security forces (Sharp \& Blanchard, 2013).

In 2011, as a follow up to the Arab Spring that started in Tunisia and swept through Egypt and Libya, anti-government protesters gathered at the Southern city of Deraa in March 2011 to demand the release of 14 School children who were arrested and reportedly tortured after writing on a wall the popular slogan of uprisings in Tunisia and Egypt: "The people want the downfall of the regime" (BBC News, 2012). Before the present uprising, Syrians struggled with many of the challenges that have bred unfathomable frustration in other Arab autocracies, including high unemployment, high inflation, limited upward mobility, rampant corruption, lack of political freedoms and repressive security forces (Sharp \& Blanchard, 2013). These factors have fuelled opposition to Syria's authoritarian government, which has been dominated by the Baath (Renaissance) Party since 1963 and the al-Assad family since 1970 (Sharp \& Blanchard, 2013).

In mid-March 2011, amid protests calling for the release of political prisoners, the Syrian national security forces responded to the pervasive initially peaceful demonstrations with brute force and from summer 2011 onwards, the Syrian President Bashar alAssad refused to halt attacks and put into action the significant reforms demanded by protesters thereby prompting the crisis (International Coalition for the Responsibility to Protect, n.d). Reports from victims, eye witnesses, the media and civil society organizations indicate that government forces had subjected civilians to arbitrary detention, torture and the deployment and use of heavy artillery as well as subjecting the Syrian people to the Shabiha (a heavily armed state-sponsored militia fighting alongside security forces) (International Coalition for the Responsibility to Protect, n.d).

Sequel to the escalation of the conflict, the anti-government forces began to limply organize, creating several opposition organization such as the Syrian National Council (SNC), an umbrella club of exiled Syrians and the Free Syrian Army (FSA), a militarized element composed mainly of Syrian military defectors and armed rebels, calling for Assad's resignation having lost patience with the lack of progress on the proposed reforms (International Coalition for the Responsibility to Protect, n.d).

Below is a tabular representation of what the protesters demand and what the Assad regime has offered.

From the above table 1, its glaring that the Assad regime never indicated interested in introducing comprehensive reforms as canvassed by the protesters as that would 
Table 1. Syrian crisis: Protesters' demand alongside government's offer

\begin{tabular}{|c|c|}
\hline What protesters want & What Assad has offered \\
\hline Fall of the regime & Mr. Assad has made clear that he has no intention to step down. \\
\hline $\begin{array}{l}\text { End to the 48-year-old } \\
\text { emergency law }\end{array}$ & $\begin{array}{l}\text { He revoked the emergency law on } 21 \text { April 2011, but Syrian forces continued to open } \\
\text { fire on demonstrations and detain people without arrest warrants. }\end{array}$ \\
\hline $\begin{array}{l}\text { Immediate end to extraju- } \\
\text { dicial killings and torture }\end{array}$ & $\begin{array}{l}\text { The president has rejected as "false" allegations made by the UN that Syrian security } \\
\text { forces have committed crimes against humanity, including killings, torture, rape, } \\
\text { imprisonment, and other forms of severe deprivation of liberty and disappearances. }\end{array}$ \\
\hline $\begin{array}{l}\text { Release of political } \\
\text { prisoners and detained } \\
\text { protesters }\end{array}$ & $\begin{array}{l}\text { Amnesties were offered to political prisoners in May } 2011 \text {, June } 2011 \text { and January } \\
\text { 2012. Officials say thousands were released, but as many as } 37,000 \text { are still in } \\
\text { prison, according to human rights activists. }\end{array}$ \\
\hline $\begin{array}{l}\text { Transition to a democratic, } \\
\text { free and pluralistic society }\end{array}$ & $\begin{array}{l}\text { On } 26 \text { February 2012, voters approved in a referendum a new constitution, which } \\
\text { sees the inclusion of political parties beyond the ruling Baath Party and drops an } \\
\text { article making the party the "leader of state and society". It also limits the president } \\
\text { to two seven-year terms. Mr Assad has also decreed on } 14 \text { March that parliamentary } \\
\text { elections will be held on } 7 \text { May. The opposition has dismissed both the constitution } \\
\text { and the elections. }\end{array}$ \\
\hline
\end{tabular}

Source: BBC News (2012, April 9).

not only lead to the down fall of the regime as the Baath ruling party only represents a narrow faction of Syrians but also probably lead to the prosecution of the former elites and the persecution of its allies as the Dutch Diplomat and Syrian scholar Nikolaos Van Dam put it: Bashar al-Assad was never going to sign his own death warrant (Holliday, 2011, n.p.).

\section{Regional and global responses to the Syrian debacle}

Since the instigation of the Syrian crisis in 2011, there has been a sharp dissection between states that resist the imposition of UN sanctions on Syria and persist in supplying arms to the Assad government and states that have imposed arms embargoes on Syria and called for a UN embargo (Wezeman, 2013). Even as the conflict intensified in 2012, the international community still remained divided as it could not forge a consensus on how to tackle the debacle in general or with supplying arms to the parties in the conflict in particular as while the European Union, the League of Arab States, Turkey and the US maintained arm embargoes against the Syrian government, Iran and Russia continued to supply the Assad government with arms (Wezeman, 2013).

In a series of public proclamations, the Special Advisers to the Secretary General on the Prevention of Genocide and on the Responsibility to Protect expressed disquiet over the Syrian government's organized extensive onslaughts targeting civilians and reminded the government of its responsibility to protect its population. In their fifth statement released on June 14,2012 , they called on the international community to take urgent decisive action to meet its responsibility to protect populations at risk of further awful crimes in Syria, taking into account the full range of instruments available under the UN 
Charter, including a referral of the situation by the Security Council to the International Criminal Court (ICC) (International Coalition for the Responsibility to Protect, n.d).

In its reaction to the Syrian cataclysm, The Human Rights Council and Office of the High Commissioner for Human Rights mandated an Independent Commission of Inquiry to probe human rights breaches in Syria and, simultaneously, restated the call for the Syrian government to assume its responsibility to protect, prevent and prosecute perpetrators of international crimes while continually urging the UN Security Council to refer the case to ICC starting from December 2011(International Coalition for the Responsibility to Protect, n.d).

For the UN Security Council, in order not to violate the UN Charter, it appointed a special envoy and established the United Nations Supervision Mission in Syria (UNSMIS) with a view to taking preventive action. Nonetheless, with the escalation of the crisis and little room for political negotiations between the disputing parties, the UNSMIS faced many technical difficulties on and off the ground, including limited freedom of movement by the government, blocked access to sites of mass violence and the rejection of observers' visas which alongside the ongoing violence led to the mission's suspension on June 15, 2012. In October 2012, the SC issued press statements disapproving the terrorist attacks in Aleppo and later calling on all important parties to execute a ceasefire in honour of Eid al-Adha. Meanwhile, numerous efforts made by the Council to resolve the conflict were vetoed by both Russia and China including the resolution to refer the perpetrators of crimes against humanity to the ICC (International Coalition for the Responsibility to Protect, n.d).

On its part, the General Assembly adopted several resolutions calling for all parties to support efforts to peacefully resolve the crisis. On May 15, 2013, the General Assembly adopted a resolution condemning the conflict's escalation, violations of humanitarian laws and violence, demanding the government meet their responsibility to protect their population, comply with international law and cooperate with the Commission of Inquiry to investigate claims of chemical weapons use (International Coalition for the Responsibility to Protect, n.d).

In an effort to forestall further bloodletting and return the country to the path of peace, UN in 2012 convened a Peace Conference in Geneva. Describing the Geneva 11 Peace Conference on Syria as a game of insults between the Syrian government and the rebels, with the Syrian Foreign Minister, Walid Muallem, accusing the opposition of immaturity while the opposition representative, Louay Safi, alleged that the Assad regime had no desire to stop the bloodshed, prompting Ahmed Jarba to liken the Geneva talks to drinking from a poisoned chalice (BBC News, 2014; Black, 2013). However, the UN-backed meeting in 2012 issued a Communiqué urging Syria to form transitional governing body, start national dialogue, review constitutional and legal system; hold free and fair elections (BBC News, 2014). 
While both sides agreed to use the 2012 Geneva Communiqué as a basis for discussions and agreed to meet in the same room but neither side could agree on the focus, with the opposition insisting that political transition were the focus and the government wanting to talk about terrorism compelling diplomats to describe the atmosphere between the two sides as extremely tense all the way through the conference (BBC News, 2014).

While the Russian Foreign Minister Sergey Lavrov and his US counterpart, Secretary of State John Kerry, affirmed their support for another Geneva Peace Conference in August 2013, however, both offered little in the way of a strategy to bring the warring sides to the table. Rebels appeared unwilling to consider a plan that does not include Assad's ouster, while Assad is unwilling to quit voluntarily as neither side seems to be willing to negotiate from a perceived position of weakness (Laub \& Masters, 2013). In addition, there was also disagreement between US and Russia over who should attend, Iran being a point of contention while the former UN-Arab League special envoy to Syria, Lakhdar Brahimi, argued that divisions within the opposition constitute further hindrance while, the allege use of chemical weapons in August 2012 and the US plan to launch punitive military action against Syria ended up complicating international discussions of a peace process (Laub \& Masters, 2013).

Since May 2011, following Assad regime's violent response to protest, the EU has imposed and heightened comprehensive sanctions, including an arms embargo, visa ban and asset freeze against individuals, organizations and the Syrian regime as a whole, while in November 2012, the EU extended recognition to the National Coalition of the Syrian Opposition as the legitimate representative of the Syrian people and subsequently, released a statement urging Assad to step down to allow for political transition in January 2013 (Holliday, 2011; International Coalition for the Responsibility to Protect, n.d). Nonetheless, sequel to the recognition of the National Coalition of the Syrian Opposition, the EU Foreign Ministers, in March 2013, modified the sanctions already in place, making it possible for European governments to bypass the ban on providing non-lethal supplies to the opposition while on May 28, 2013, the member states of the EU effectively terminated the arms embargo on the opposition in Syria, opening up the prospect of arming anti-government rebels while upholding arms embargo against the Assad regime (International Coalition for the Responsibility to Protect, n.d).

While the majority of the remaining EU member states are concerned that further militarization will only stimulate more violence, nevertheless, only France and the United Kingdom have expressed readiness to supply arms to the rebels (International Coalition for the Responsibility to Protect, n.d). Beyond the country specific aspect of the EU regional strategy for Syria, Iraq and Da'esh threat which was adopted in March 2015 and reviewed in May 2016, the EU strategy for Syria which comprises the Foreign Affairs Council Conclusions of April 3, 2017 alongside the Joint Communication by the High Representative and the Commission of March 14, 2017, places emphasis on six areas: 
in accordance with United Nations Security Council Resolution (UNSCR) 2254, pursue an end to the Syrian war via negotiated political transition with the support of regional and international actors under the umbrella of UN Special Envoy for Syria; in line with UNSCR 2254 and the Geneva Communiqué, foster meaningful and all inclusive transition in Syria by supporting political opposition, provide humanitarian assistance to vulnerable Syrians, promote democracy, human rights and freedom of speech by strengthening Syria's civil society organizations, ensure accountability for war crimes with a view to facilitating a national reconciliation process and transitional justice and support the resilience of the Syrian population and society (European Commission, 2017a). In the area of aid, as a leading international donor, the EU, alongside its member states, has collectively donated 9.4 billion Euro for humanitarian and development assistance in addition to 3.7 billion Euro pledged in April 2017 at the Brussels Conference (European Commission, 2017b)

At the instance of the Turkish government, the North Atlantic Treaty Organization (NATO), despite its stance not to interfere in the Syrian conflict, in January 2013, placed patriot missiles on Turkey's border with Syria to guard against external attack after five Turkish civilians were murdered by Syrian mortar fire in October 2012 and another 13 people were killed in an explosion on Turkish-Syrian border in February 2013 (International Coalition for the Responsibility to Protect, n.d). In addition, the main opposition, The Republican People's Party (CHP), accused the ruling Justice and Development Party (AKP) led-government of providing logistical, military and medical support to ISIS militants fighting the Syrian regime; the CHP Deputy Chairman Muharrem Ince revealed that ISIS commander, Abu Mohammad, had received medical treatment at the Hatay State Hospital in Turkey on April 16, 2014 (Paul, 2014). Furthermore, another top-ranking opposition party official, Ihsan Ozkes who is CHP Istanbul deputy charged that al-Qaeda affiliated al-Nusra Front militants have received medical treatment at the guest houses run by Turkey's Religious Affairs Directorate (DIB) under the supervision of the National Intelligence Organization (MIT) (Paul, 2014).

For Lebanon, the incursion of refugees and increased cross-border fire from Syria has threatened to enmesh it in its neighbour's catastrophe notwithstanding its long policy of disassociation in the Syrian cataclysm. Moreover, a signal surfaced recently that the Syrian crisis is gradually degenerating into a full-blown regional emergency subsequent upon the entry of the Lebanese Hezbollah and its role in aiding the Syrian government re-take the city of Qusayr in June, 2013 ((International Coalition for the Responsibility to Protect, n.d).

Iran, Syria's long-time ally, has been unrelenting in maintaining vital contacts with the Assad regime in Damascus, having supplied it with both military and much needed economic assistance, including helping the regime to evade western sanctions on oil 
export in addition to the Iranian Basij militia that is suspected to have aided in training the Syrian Shabiha, the militia incriminated in the brutal Houla massacre (Laub \& Masters, 2013).

On its part, China has sustained economic, political and military ties with Syria notwithstanding disparagement from Arab and western leaders. China and Russia have vetoed three western-backed UN Security Council resolutions that incorporated language alluding to the responsibility of the Assad government to protect the civilian population as well as the fourth one seeking to refer all those involved in crimes against humanity to the International Criminal Court (ICC) (International Coalition for the Responsibility to Protect, n.d.)

On its part, the Arab League led by the Sunni Arab Gulf States, while disapproving any unilateral action in response to the Syrian conflict, introduced a peace plan after about nine months of violence against civilians, called on the Assad regime to halt violence, release prisoners, allow for media access and remove military presence from civilian areas (International Coalition for the Responsibility to Protect, n.d.). However, following the failure of the Assad regime to abide by the peace plan after initial agreement to act accordingly, the 22-member regional body approved far-reaching package of measures censuring Syria, clearing the way for a considerable intensification of international pressure against President Bashair al-Assad and deepening the isolation of his increasingly embattled government. The adoption of a resolution suspending Syria's membership on November 12, 2011, imposing economic sanctions against it on November 27, 2011 and seeking UN help unless the Syrian government stops using violence to suppress the country's uprising at an emergency meeting in Cairo, signified an extraordinary show of Arab solidarity against a fellow regional power, being the third time a nation has been suspended (Sly, 2011; International Coalition for the Responsibility to Protect, n.d.).

Besides, on January 29,2012, on account of critical conditions in the country even after Syria signed a peace deal on December 19, 2011, the Arab League suspended an Arab observer mission mandated by Syria to observe and report on the crisis, encouraged the UN Security Council to take further action and appointed a Joint Special Envoy with the UN to facilitate a political solution to the crisis; while in November 2012, in a bid to have a more inclusive and representative model, the League alongside the Gulf Cooperation Council recognized the National Coalition of the Syrian Opposition (an opposition organization formed that same month from various opposition groups) as the legitimate representative and main interlocutor with the Arab League and Gulf Cooperation Council and in March 2013, the Coalition official took Syria's seat at the summit of the Arab League (International Coalition for the Responsibility to Protect, n.d.). 


\section{US role in the lingering fratricide in Syria}

To properly conjecture and appreciate US stand on the persistent conflict in Syria, it is imperative we start with brief background information on American perception of Syria. According to the US State Department, Syria is on the list of 'State Sponsors of Terrorism' for providing financial aid, political support, weaponry and military training to terrorists organizations such as the Iran-backed Hezbollah and Hamas as well as Palestinian Islamic Jihad, the Al-Aqsa Martyrs Brigades and other extremist groups (United States Department of State, n.d.)

In February 2010, for instance, it was reported that former Iranian President Mahmoud Ahmadinejad, Hezbollah leader, Hassan Nasrallah and leaders from several Palestinian terrorist groups were hosted to a dinner at Damascus during which the Syrian leader Bashar Assad and his Iranian counterpart Mahmoud Ahmadinejad reiterated their two countries string ties with disdain for Israel, US foremost ally (Nahmias, 2010).

At the beginning of the Syrian crisis, for fear of the weapons so transferred entering the wrong hands as well as forestall a situation where the US would be dragged to a proxy war on another side, the Obama administration was foot dragging on the propriety of providing anti-government forces with training and lethal aid. As argued by Miller and Warrick (2012), the lack of intelligence has complicated the Obama administration's capacity to navigate a crisis that presents an opportunity to do away with a long time US adversary but carries the danger of strengthening insurgents sympathetic to al-Qaeda or militant Islam.

However, in February 2013, Obama approved an order known as 'intelligence finding' that largely authorized the CIA and other US agencies to provide aid that could help the rebels dislodge Assad from power. According to the State Department, under the President's Secret Order, the US government had set aside a total of $\$ 25$ million for non lethal assistance -food and medical kits to the rebels including CIA supplied encryptionenabled communications gear that would allow the US monitor the conversations of the opposition groups (Al Jazeera, 2013; Miller \& Warrick 2012; Laub \& Masters, 2013).

In June 2013, sequel to reports that the Assad regime used chemical weapons against rebel fighters in 2012, US hid the call by the rebel forces for governments supporting their cause to supply them with weapons and other military equipment by authorizing the Central Intelligence Agency (CIA) to provided small arms and ammunition to vetted rebel groups (Laub \& Masters, 2013; Wezeman, 2013). Following this directive, the US, alongside its Middle East allies of Saudi Arabia and Qatar, decided to arm the Syrian rebels under the umbrella of 'Free Syrian Army' (Boyd, 2014). As reported in The Telegraph UK, former Yugoslavian Army weapons held by the Croatians together with newly manufactured Croatian armaments were flown out of Croatia on chartered flights to Jordan and then smuggled into Syria while M79 rockets were transferred by 
Saudi from Croatia according to AFP report (Boyd, 2014). Also, an independent news website, WND, reported that in 2012, CIA trained ISIS members at a secret base in Jordan to fight the Syrian government (Paul, 2014).

In a related development, the US Republican Senator Rand Paul stated that the US government has been arming ISIS militants in Syria and funding its allies. According to him: "They are emboldened because we have been supporting them ... It could be Assad (could have) wiped these people out months ago" (Paul, 2014, para.3). He adds thus: "I personally believe that this group would not be in Iraq and would not be as powerful had we not been supplying their allies in the war" (para.4).

Admitting that contrary to allusions that the US was unwillingly drawn into the dreadful conflict caused by others, Davies (2013) has identified nine (9) ways in which the US has been sabotaging the peace efforts, thereby fuelling the crisis as shown in the table below:

Table 2. 9 Ways America Has Fuelled the Bloody Civil War in Syria

\begin{tabular}{|c|c|}
\hline Instance & Comments \\
\hline $\begin{array}{l}\text { Formation of Syrian National } \\
\text { Council (SNC) outside } \\
\text { the National Coordinating Body } \\
\text { for Democratic Change (NCB) }\end{array}$ & $\begin{array}{l}\text { Following the outbreak of the Arab Spring in 2011, the left wing protesters in } \\
\text { Syria formed the National Coordinating Body for Democratic Change (NCB) } \\
\text { to coordinate peaceful protests and resistance to government repression } \\
\text { based on three fundamental principles of non-violence, non-sectarianism } \\
\text { and no foreign intervention. The US and its allies however, sidelined the NCB } \\
\text { and formed an unrepresentative government-in-exile in Turkey known as the } \\
\text { Syrian National Council, recruited, armed and trained violent groups to pursue } \\
\text { regime change. }\end{array}$ \\
\hline $\begin{array}{l}\text { Replication of Libyan strategy } \\
\text { on Syria by US and its allies }\end{array}$ & $\begin{array}{l}\text { Sequel to regime dethronement in Libya, the US, the United Kingdom, France, } \\
\text { Turkey, Saudi Arabia and Qatar adapted the same strategy to Syria which saw } \\
\text { them fly in fighters, weapons and equipment to turn the Syrian uprising into } \\
\text { a bloody civil war. }\end{array}$ \\
\hline $\begin{array}{l}\text { Arming, training and financing } \\
\text { of rebels by US-led NATO forces }\end{array}$ & $\begin{array}{l}\text { Despite the outcome of a Qatari-funded YouGov poll in December } 2011 \text { which } \\
\text { indicates that } 55 \% \text { of Syrians still supported their government, unmarked } \\
\text { NATO planes were flying fighters and weapons from Libya to the Free Syrian } \\
\text { Army base at Iskanderum, Turkey. In addition, special forces from Britain and } \\
\text { France provided communications equipment and intelligence as it happened } \\
\text { in Libya. }\end{array}$ \\
\hline Recruitment of foreign fighters & $\begin{array}{l}\text { In June } 2013 \text {, anti-government sources acknowledged that } 2,100 \text { of the } \\
16,700 \text { rebel fighters killed so far in Syria were foreigners, while only } 145 \text { of } \\
41,600 \text { loyalists killed in action were foreign Hezbollah members. }\end{array}$ \\
\hline $\begin{array}{l}\text { Commercialization } \\
\text { of the war in Syria }\end{array}$ & $\begin{array}{l}\text { Balkans Journalists reported that wealthy Gulf Arab paymasters fund } \\
\text { hundreds of hardened mercenaries from Croatia and elsewhere, who earn up } \\
\text { to } \$ 2,000 \text { per day as rebel snipers and special forces in Syria. Saudi Arabia for } \\
\text { instance sent convicts to fight in Syria and funded shipments of weapons from } \\
\text { Croatia to Jordan while Qatar spent } \$ 3 \text { billion to pay rebel fighters and shipped } \\
\text { at least } 70 \text { plane loads of weapons via Turkey. }\end{array}$ \\
\hline
\end{tabular}


Instance

Double standard on the part of US and its Western and Arab allies

Reneging on the Geneva Agreement via direct weapons shipments and missile strikes to support Syrian proxies process

\section{Comments}

At the Orwellian Friends of Syria meetings to launch what French officials referred to as a Plan B, the US joined France and its other allies to undermine the Annan peace plan thereby escalating the war. Nine days before Annan's ceasefire was due to take effect at the second Friends of Syria meeting, the US and its allies agreed to provide funds for the Free Syrian Army to pay its fighters, while Qatar and Saudi Arabia pledged to increase their weapons delivery.

Inconsistent stance over the fate of Assad in the political transition

When Kofi Annan assembled all the permanent members of the UN Security Council and other governments involved in the Syrian debacle at the end of June 2012 in Geneva, the Western powers briefly dropped their previously non-negotiable demand to oust Assad as the first towards political transition to enable all sides finally sign on to the Annan peace plan. However, when it came to the codification of the Agreement, the US and its allies rejected a UN Security Council Resolution in that regard and revived their previous demands calling for Assad to quit.

After tens of thousands of Syrians were massacred in May 2013, US Secretary of State, John Kerry went to Moscow and agreed to renew the peace process started in June 2012 in Geneva. Nevertheless, since May, the US has once again reneged on the Geneva Agreement and decided to escalate the war even further, by providing direct weapons shipments and now missile strikes to support its proxies in Syria.

Source: Author's original adaptation from Davies N.J.S (2013, September 4).

9 Ways America has fuelled the Bloody Civil War in Syria.

The foregoing notwithstanding, in its pledge to helping the innocent children, women and men affected by the ongoing conflict in Syria, the US remains the single largest donor of humanitarian aid for those affected by the crisis described as biggest humanitarian emergency of our era . Syria fact sheet released as at December 11, 2015, shows that total US Government Assistance to the Syrian Humanitarian Response FY2012-2015 is $\$ 4,529,063,219$ comprising the following: USAID/OFDA $\$ 866,283,413$, USAID/FFP $\$ 1,550,694,720$ and State/PRM \$2,112,085,086 (USAID, 2015).

\section{Russia's position on the Syrian Crisis}

Sequel to Russia's rejection of what it perceives as a world order dominated by the US and the need to balance it by boosting its (Russia's) position in the Middle East dominated by Israel's principal ally, the US, Moscow has moved to cement relationship with its age-long ally in the Middle East, Syria. On Wednesday, May 11, 2010, prior to the commencement of the Syrian conflict, former Russian President and current Prime Minister, Dmitry Medvedev, visited Damascus to hold talks with his Syrian counterpart, Bashar al-Assad on nuclear energy cooperation between the two countries. The visit, the first of its kind in the history of the relationship between Russia and Syria for a Russian or Soviet President to visit Syria, came amid tension over Israel's accusations that Syria has been transferring long-range scud missiles to the Lebanese militia - Hezbollah (Black, 
2010). Declaring that all nations have the right to peaceful nuclear power programmes, during the visit, Dmitry Medvedev voiced his country's preparedness to build a nuclear power station in Syria as it had long been doing in Iran (Syria's main regional ally) despite the apprehension expressed by the US through State Department spokesman Philip Crowley that countries looking at energy cooperation with Syria should be aware of Syria's shortcomings on nuclear matters (Libnan, 2010).

As Syria gets overwhelmed in over six-year old uprising, Russia continues to maintain economic and military relations, including arms sales to the Assad regime despite mounting international condemnation over the Syrian regime's bloody crackdown in which about 465,000 people have so far been killed and missing (McDowall \& Glover, 2017). According to a report by The Syrian Observatory for Human Rights (a monitoring group based in Britain), over 321,000 people have been killed while more than 145,000 are declared missing (McDowall \& Glover, 2017). Continuing, the report documented over 96,000 civilian deaths; out of which government forces and their allies are responsible for more than 83,500 deaths including 27,500 that died as a result of air strikes and 14,600 through prison torture; shelling from anti-government forces claimed more than 7,000 lives; Islamic State Jihadists have killed more than 3,700 while air strikes by the US-led coalition and Turkey (which is supporting the rebels) have killed 920 and more than 500 civilians respectively (McDowall \& Glover, 2017).

Amid escalating economic downturn occasioned by low oil prices, as well as Western sanctions imposed on Russia over its actions in Ukraine, the Syrian fractricide has enabled Moscow enhance its status as major arms producer and exporter, making it the second largest after the United States (Mirovalev, 2016). As Moscow expects to wreck in $\$ 7 \mathrm{bn}$ in arms sales due to the crisis in Syria as reported by Kommersant daily, the country's foreign minister, Sergei Lavrov, has affirmed that Russia will continue with military supplies to Syria accompanied by the dispatch of Russian experts that will assist in adjusting the equipment and training the Syrian personnel on how to handle the weapons (Golubkova, 2015). Beyond arms sales, Russia has been directly involved in the ongoing war in Syria. For instance, four Russian warships launched long range cruise missiles that hit eleven targets on October 7, 2015 (marking Russian President's $63^{\text {rd }}$ birthday) while in December that same year, a Russian submarine submerged in the Mediterranean sea launched similar cruise missiles against targets at Raqqa province of Syria (Mirovalev, 2016).

Also, Russia has vetoed, on eight different occasions, Western-backed UN Security Council Draft Resolutions aimed at isolating Assad regime since the war started in 2011 while China (Russia's key supporter) has vetoed same six times and abstained on two occasions (Mckirdy, 2017). Though several reasons have been adduced for Russia's support for the Syrian regime ranging from Middle East geopolitics, Cold War-era Alliances, arms sales and even special interests such as the under-renovation Tartus naval resupply 
facility that enables Moscow operate on the Mediterranean, however, the key motivation is the world order (Trenin, 2012). Drawing from Libyan experience where UN humanitarian operation to save lives in Benghazi was abused by North Atlantic Treaty Organization, Russia considers it an error of strategic judgement to create room for unrestricted US forceful intervention in Syria as that might trigger foreign interventions either close to Russian borders or even within the borders such as the North Caucasus (Trenin, 2012). Moreover, Moscow's support is predicated upon the fear that an Islamist Spring will enable radical groups and al-Qaeda allies to gain ground close to Russia's troubled North Caucasus (Trenin, 2012).

In September 2013, amid likelihood of US airstrikes against the Assad regime due to the latter's alleged use of chemical weapons in contravention of its obligations under the Chemical Weapons Convention (CWC) which forbids State Parties to develop, produce, otherwise acquire, stockpile or retain chemical weapons or transfer, directly or indirectly, chemical weapons to anyone, not use chemical weapons, not to engage in military preparations for use of chemical weapon, not to assist, encourage or induce anyone to engage in any activity prohibited to a State Party under the Convention, Russia provided reprieve to the Assad regime by suggesting that rather than launch an airstrike, the Syrian regime should be made to surrender its chemical weapons to international monitors from the Organization for the Prohibition of Chemical Weapons (OPCW) for destruction (Nuclear Threat Initiative, 2017; Laub \& Masters, 2013).

Consistent with its protection of President Bashar al-Assad and his administration from severe pressure or censure, for the fourth time, Russia, supported by China, blocked a Security Council Resolution (that was supported by 13 out of 15 members) seeking to refer all those responsible for war crimes and crimes against humanity to the International Criminal Court (ICC) (Black, 2014). Summarizing Russia's stand on the Syrian conflict, Holliday (2011) has, however, opined that commercial and military interests in Syria have solidified Russian support for Assad.

Four reasons have been identified as accounting for Russia's persistence support for the al-Assad's regime in Syria:

1. Russia has a naval installation (Tartus naval base) in Syria, which is strategically important as well as considered as Russia's last foreign military base outside former Soviet Union. There is the belief among the Russian public that the fall of Assad would be equivalent to the defeat of Russia's last client and ally in the Middle East and the ultimate abolition of traces of former Soviet powers there.

2. Russia still harbours a bit of Cold War mentality, as well as a touch of national insecurity, which makes it bother so much about maintaining one of its last military alliances. Russia conceives of Arab Revolutions as having entirely undermined the region, paving the way for the ascendancy to power by Islamists. Having suffered from terrorism and extremism at the hands of Islamists in the Northern Caucasus, 
Moscow perceives secular authoritarian governments as the lone pragmatic substitute to Islamic domination.

3. Russia abhors the notion of international intervention against countries like Syria because it sees this as a Cold War style Western imperialism and, ultimately, a threat to Russia. The recent Russian policy on Syria essentially dwells on supporting Assad government and averting external intervention directed at deposing it as occurred in Libya, where the west blatantly interpreted the resolutions adopted by the UN Security council, directly violated those resolutions and unilaterally intervened in the country's affairs. It is believed that western intervention in Syria which Moscow cannot counteract militarily would be a premeditated sacrilege on one of the few enduring symbols of Russia's status as a great world power.

4. Syria imports a lot of Russian military equipment as the later needs the financial gains. The implication of this that Russia having concluded a number of arms sales and energy contracts with the regime, appears worried about not getting paid if Assad is overthrown (Fisher, 2013; Pukhov, 2012).

To corroborate the claim that Russian policy fuels the crisis in Syria, it has been argued that Russia's support for Syria via sending lots of weapons has made it easier for Assad to keep maiming civilians as well as made it much difficult in case the outside world wants to intervene. Moreover, whether or not one thinks military action is a welcome development, the undisputable fact remains that Russia's support for Assad makes him less likely to negotiate or accept a peace deal if he (Assad) thinks he can win outright (Fisher, 2013). It is in the light of this that United Nations Special Envoy to Syria, Staffan de Mistura, has urged the world to listen more closely to Russia on the four-year long crisis that has cost more than 210,000 lives and fuelled an unprecedented growth of Islamist extremism that has spread across the Middle East, stressing that Russia not only has influence on Damascus but also a good knowledge of how the Syrian system works and the way the people there think as the relationship between the duo dates back to the period when Bashar al-Assad's father was in power (Halliburton, 2015).

Notwithstanding the role being played by the two major global actors (Russia and US), some pertinent questions deserve consideration here: Are there other influential actors involved in this crisis, especially at the regional level? If there are, would the exit of Russia and US put an end to their involvement in the Syrian cataclysm? From the Russian perspective, Iran and Saudi Arabia as two influential regional actors that must be involved in any discussion aimed at finding a solution to the Syrian debacle. As noted by the Russian Ambassador to the United Nations, Vitaly Churkin, the collapse of preceding rounds of negotiations on Syria was occasioned by the absence of key regional players, especially Iran (Churkin, 2014). The importance of involving Iran and Saudi Arabia had earlier been emphasized by Russian Foreign Minister, Sergei Lavrov, when he declared that it will be a great mistake to exclude the duo from any future discussions 
on the Syrian crisis, stressing that all Syrian neighbours without exception should be represented at the negotiating table (Churkin, 2014).

With mention being made of Iran and Saudi Arabia, let us x-ray the involvement of the two states in the lingering Syrian upheaval. Well before the recent crisis in Syria, Iran has been Syria's key ally in the Middle East, bound together by religion and strategy. From the religious dimension, Iran remains the most populous Shiite Muslim nation in the world and Assad's Alawites is an offshoot of Shiite. This religious affinity has brought the two countries together for a long period of time such that during the Iran-Iraq war that lasted for eight years, Syria was the only Arab ally that stood by Iran (Yan, 2013). Arising from this common religious background, the last thing Iran would condone is a Syria dominated by the Sunnis. This is more so as the opposition groups are backed by Iran's Persian Gulf rivals, Saudi Arabia and Qatar (Yan, 2013). In terms of military strategy, Syria serves as the main conduit through which Iran supplies weapons to Hezbollah, considered as the most Shiite militia in Lebanon, fighting alongside Syrian government forces as well as serving as the proxy through which Iran can threaten Israel (Syria's arch enemy) with an arsenal of short-range missiles (Manfreda, 2014; Yan, 2013). As the Syrian uprising morphed into resistance, Iran, in its interest to ensure that al-Assad remains in power, has provided significant support in the area of intelligence, communication, advice on crowd control and weapons (Yan, 2013).

For Saudi Arabia, after the 2003 US-led intervention in Iraq, positive relations between Saudi Arabia and Syria began to loosen speedily. Confronted with Iran's increasing regional clout, the ascendancy to power of a Shiite government in Iraq with close links to Iran unsettled Riyadh, making it exceedingly difficult to accommodate the interests of Assad-led regime supported by Iran (Manfreda, 2014). Manfreda (2014) has identified two major flashpoints that have drawn Assad into an unavoidable clash with Saudi Arabia: One is that Syria is the main channel for the flow of weapons from Iran to Lebanese militia, Hezbollah, hence, it is anticipated that the fall of Assad regime would cut back on Hezbollah's access to weapons and significantly boost the influence of Saudi-backed Lebanese groups opposed to Hezbollah. Two, refers to the activities of Syria in Palestine. By tradition, Syria has supported radical Palestinian groups such as Hamas, who are averse to dialogue with Israel, while Saudi Arabia supports the rival Fatah of Palestinian President Mahmoud Abbas, who advocate peace talks with Israel. At the outburst of the Syrian unrest following the Arab Spring, Riyadh, prompted by decades long craving to sever the alliance between Syria and Iran, saw an opportunity to use its oil wealth to arm the Syrian rebels, hoping to replace the Assad regime with a friendly government in the event that the former collapses (Manfreda, 2014).

With the foregoing background information on the activities of Iran and its major contender for regional dominance, Saudi Arabia, is it possible that the withdrawal of the 
two dominant global actors in the Syrian uprising would affect these two countries (Iran and Saudi Arabia) in the same direction or will they behave differently? The withdrawal of US and Russia (two permanent members of the UN Security Council) from the conflict in Syrian will undoubtedly send a strong signal to all their allies both within the Middle East region and beyond that any form of support to either of the parties to the dispute will not be welcome. The success recorded by the US over the Suez Canal crisis of 1956 involving Britain, France and Israel on one side and Egypt on the other side underscores this position. In this particular incident, the US was able to pressure Britain and France (who had earlier used their veto to prevent the ceasefire called for by the UN Security Council) from intervening in Egypt and getting rid of Nasser after he nationalized the Suez Canal under the pretext of warding off a threat to the Canal in the event that Israel, instigated by both invaded Egypt (Nye, 2003).

The activities of the two key regional actors, Iran and Saudi Arabia competing for dominance in the Persian Gulf and the wider Middle East can easily come under check. For instance, the US can leverage on its long term relationship with Saudi Arabia to reign in the later and other Arab countries such as Turkey and Qatar while Russia can ride on the strategic partnership between it and Iran to curtail the latter's involvement in the crisis. It is on record that Iran's first nuclear power reactor Bushehr 1 reactor which is at the centre of frosty relationship between Tehran and Washington, was completed by the Russian Ministry of Atomic Energy (Minatom) in addition to the new deal to broaden military cooperation between the two countries underscores the depth of the relationship between Moscow and Tehran.

In addition, the exit of the great powers will also create a common platform for the UN Security Council to chart a common front towards ending the Syrian crisis as this had hitherto hindered all efforts in that direction. Most importantly, it will foster the consensus required by the UN Security Council to enforce the Responsibility to Protect (RtoP or R2P) the Syrian population from genocide, war crimes, crimes against humanity and ethnic cleansing including the incitement of these groups by any group, be it state or non state actors. It is recorded that a meeting of the permanent members of the UN Security Council on the Syrian catastrophe ended less than an hour after being organized by Russia, a staunch ally of the Assad regime (Pace \& Matthew, 2013). Suffice it to state that some analysts are of the view that the belated action by regional actors such as the League of Arab State and the Gulf Cooperation has hampered the Syrian peace process, nevertheless, a major obstacle on the way of securing peace is the failure of the UN Security Council of which Russia and US are permanent members enjoying veto powers, to reach a compromise on decisive action to end the conflict. 


\section{Conclusion}

This paper has attempted to explain how the popular Arab Spring that started in Tunisia and swept through Egypt and Libya triggered a peaceful protest and the subsequent escalation of this demonstration to a full-scale civil war as a result of bloody crackdown on protesters by Syrian security forces and how the battle of wigs between the US and Russia has exacerbated rather than ameliorated the situation. The inherent contradictions in the handling of the Syrian catastrophe by the two great powers raise serious doubt as to their avowed commitment in finding a lasting solution to the Syrian crisis given that none of them is willing to sacrifice its foreign policy objective and national security interest on the altar of win-win settlement option acceptable to the key actors in the long drawn civil war. It further casts doubt as to the prospect of external parties other than Syrians to nip the conflict in the bud.

The botched attempts at using UN Security Council to resolve the Syrian quagmire due to lack of consensus among its members as illustrated in the veto of its western-backed resolutions by Russia and China as well as the inability of the Office of the Secretary General on the Prevention of Genocide and on the Responsibility to Protect to assume the responsibility of protecting the Syrian population against war crimes and crimes against humanity, underscores the urgent need for the Assad led Syrian government to gear up to the challenge of resolving this impasse. While it thus appears late however, it is better than never as Bashar al-Assad ought to learn a lesson from the attendant consequences and far-reaching repercussions on both the personality and the entire country occasioned by the intransigence of Egypt's Mubarak, Libya's Ghadafi in the aftermath of widely celebrated Arab Spring.

Leadership also entails sacrifice. To avert further bloodletting, it will be patriotic and states manly for Assad to step down, paving the way for the formation of an all inclusive transitional government of national unity that will initiate the process of national reconciliation and reconstruction. In the interest of Syria and its people, Assad should emulate the immediate past Iraqi Prime Minister, Nouri al-Maliki who accepted the candidacy of Haider al-Abadi and stepped down after he was rejected by the stakeholders to save his country from political turmoil. Also worthy of emulation is the humanitarian spirit exhibited by former interim Vice President of Egypt, Mohamed ElBaradei, who quit the Egyptian government amid use of force by security forces against members of the Muslim Brotherhood protesting the ouster of President Mohamed Morsi after declaring that he (Mohamed ElBaradei) cannot account for one Egyptian blood.

Assad should strive to read and heed the lesson of history by relinquishing power as the prevailing mood in Syria today does not favour his continued hold on power. This is where Yolamu Barongo's actors' perception, interpretation and response to environmental stimuli as one of the tripartite determinants of the nature of political life, the 
type of institutions that are created and sustained and the peculiar patterns of political processes that emerge in any given society become instructive.

\section{References}

1. Agi, S. P. I. (1998). Political history of religious violence in Nigeria. Calabar: Ushie Printing and Publishers.

2. Al Jazeera. (2013, November 18). Obama signs secret order to aid Syria rebels. Al Jazeera Retrieved from www.aljazeera.com/news/middleeast/2012/08/201282645107242 49.html.

3. BBC News. (2012, April 9). Guide: Syria crisis. BBC News. Retrieved from www.bbc. co.uk/news/world-middle-east-13855203.

4. BBC News. (2014, January 31). Syria crisis: Geneva peace talks end in recriminations. $B B C$ News. Retrieved from www.bbc.com/news/world-middle-east-25983181.

5. Black, I. (2010, May 11). Syria and Russia in talks on nuclear power. The Guardian. Retrieved from www.theguardian.com/world/2010/may/11/syria-russia-nuclear-talks.

6. Black, I. (2013, October 22). Can a new Syria peace conference in Geneva stop the worsening crisis? The Guardian. Retrieved from www.theguardian.com/commentis free/2013/oct/22/can-syria-peace-conference-geneva-stop-crisis.

7. Black, I. (2014, May 22). Russia and China veto UN move to refer Syria to International Criminal Court. The Guardian. Retrieved from www.theguardian.com/world/2014/ may/22/russia-china-veto-un-draft-resolution-refer-syria-international-criminalcourt.

8. Boyd, K. (2014, September). Remember those moderate Syrian rebels that the US armed? ISIS got some of those weapons too. Independent Journal Review. Retrieved from http://ijreview.com/2014/09/175685-remember-moderate-rebels-syria-obamaarmed-isis-got-weapons/.

9. Churkin, V. (2014, October 31). Russia: Iran should be part of solution to crisis in Syria. Iran Daily. Retrieved from www.iran-daily.com/News/14639.html.

10. Davies, N. J. S. (2013, September 4). 9 ways America has fuelled the blody civil war in Syria. Alternet. Retrieved from www.alternet.org/world/america-has-fueled-bloodycivil-war-syria.

11. Euronews. (2017, March 17). The economic costs of Syria's civil war. Euronews. Retrieved from www.euronews.com/2017/03/17/the-economic-costs-of-syria-s-civilwar.

12. European Commission. (2017a, April 5). The EU and the crisis in Syria. European Commission. Retrieved from http://europa.eu/rapid/press_release_MEM0-16-3028_ en.htm.

13. European Commission. (2017a, May). European civil protection and humanitarian aid operations. ECHO factsheet. Brussels: European Commission.

14. Fisher, M. (2013, September 5). The four reasons Russia wont give up Syria, no matter what Obama does. Washington Post. Retrieved from www.washingtonpost.com/ 
news/worldviews/wp/2013/09/05/the-four-reasons-russia-wont-give-up-syria-nomatter-what-obama-does/?utm_term=.6c183421c9a2.

15. Golubkova, K. (2015, September 13). Russia to continue supplying arms to Syria. Independent. Retrieved from www.independent.co.uk/news/world/middle-east/russiato-continue-supplying-arms-to-syria-10498761.html.

16. Halliburton, R. (2015, April 12). Syria conflict: Listen to Russia to help resolve crisis, urges UN envoy. Independent. Retrieved from www.independent.co.uk/news/world/ middle-east/syria-conflict-listen-to-russia-to-help-resolve-crisis-urges-un-envoy-10 171782.html.

17. Holliday, J. (2011, December 6). The struggle for Syria in 2011. An Operational and Regional Analysis. Middle East Security Report 2. Washington: Institute for the Study of War.

18. International Coalition for the Responsibility to Protect (n.d.). The crisis in Syria. ICRtoP. Retrieved from www.responsibilitytoprotect.org/index.php/crises/crisis-in-syria.

19. Kegley, C. W. Jr. (2007). World politics: Trend and transformation (11 ${ }^{\text {th }}$ ed.). Belmont, CA: Thomson Wadsworth.

20. Laub, Z., \& Masters, J. (2013, September 11). Syria's crisis and the global response. Council on Foreign Relations. Retrieved from www.cfr.org/syria/syrias-crisis-globalresponse/p28402.

21. Libnan, Y. (2010, May 13). US signals unease over Russian-Syrian civilian nuclear talks. Retrieved from YaLibnan. Retrieved from http://yalibnan.com/2010/05/13/us-signals-unease-over-russian-syrian-civilian-nuclear-talks/.

22. Manfreda, P. (2014, June 18). Saudi Arabia and Syrian uprising. ThoughtCo. Retrieved from www.thoughtco.com/saudi-arabia-and-syrian-uprising-2353552.

23. McDowall, A., \& Glover, J. (2017, March 13). Syrian war monitor says 465,000 killed in six years fighting. Reuters. Retrieved from www.reuters.com/article/us-mideast-cri sis-syria-casualties/syrian-war-monitor-says-465000-killed-in-six-years-of-fightingidUSKBN16K1Q1

24. Mckirdy, E. (2017, April 13). 8 times Russia blocked a UN Security Council Resolution on Syria. CNN. Retrieved from www.edition.cnn.com/2017/04/13/middleeast/Russiaunsc-syria-resolutions/index.html.

25. Mercy Corps. (2017, March 9). Quick facts: What you need to know about Syrian crisis. Mercy Corps. Retrieved from www.mercycorps.org/articles/iraq-jordan-lebanon-syriaturkey/quick-facts-what-you-need-know-about-syria-crisis.

26. Miller, G., \& Warrick, J. (2012, July 23). In Syria conflict, US struggles to fill intelligence gaps. Washington Post. Retrieved from www.washingtonpost.com/world/nationalsecurity/in-syria-conflict-us-struggles-to-fill-intelligence-gaps/2012/07/23/gJQAW8 DG5W_story.html?utm_term=.61ac0e951ec6.

27. Mirovalev, M. (2016, April 6). Syria's war: A showroom for Russian arms sales. Aljazeera. Retrieved from www.aljazeera.com/news/2016/04/syria-war-showroom-russianarms-sales-160406135130398. 
28. Nahmias, R. (2010). Iran: New Middle east wont include Zionists. YNetNews. Retrieved from www.ynetnews.com/articles/0,7340,L-3854486,00.html.

29. Nuclear Threat Initiative (NTI). (2017, January, 25). Convention on the prohibition of the development, production, stockpiling and use of chemical weapons and on their destruction (CWC). NTI. Retrieved from www.nti.org/learn/treaties-and-regimes/con vention-prohibition-development-production-stockpiling-and-use-chemical-weap ons-and-their-destruction-cwc/.

30. Nye, J. S. (Jr). (2003). Understanding international conflicts: An introduction to theory and history, $4^{\text {th }}$ ed. New York: Longman.

31. O’Brien, S. (2017, May 31). The worsening humanitarian crisis in Syria. Inter Press Service. Retrieved from http://ipsnews.net/2017/05/the-worsening-humanitariancrisis-in-syria/.

32. Pace, J., \& Matthew, L. (2013, August 29). Syria defiant as UN chemical probe nears end. Global Gathering.Retrieved from www.global-gathering.com/news/10810.

33. Paul, R. (2014, June 22). US arming ISIS terrorists. PressTV. Retrieved from www. presstv.com/detail/2014/06/22/368155/rand-paul-us-arming-isis-terrorists/.

34. Pukhov, R. (2012, July 6). Why Russia supports Syria. New York Times. Retrieved from www.nytimes.com/2012/07/07/opinion/why-russia-supports-syria.html?mcubz=1.

35. Sharp, J. M., \& Blanchard C. M. (2013, September 6). Armed conflict in Syria: Background and US response. Congressional Research Service Report prepared for Members and Committees of the Congress.

36. Simeon, U. (2001). Political violence in Nigeria as the aftermath of colonial experience: An appraisal (Unpublished undergraduate project), University of Calabar, Nigeria.

37. Sly, L. (2011, November 12). Syria suspended from Arab League. Washington Post. Retrieved from www.washingtonpost.com/world/syria-suspended-from-arab-league/ 2011/11/12/gIQAvqGxEN_story.html?utm_term=.06fd7020a439.

38. Trenin, D. (2012, June 28). Syria: A Russia perspective. Carnegie Endowment for International Peace. Retrieved from www.carnegieendowment.org/sada/?fa=48690.

39. US Agency for International Development (2015, December 11). Syria complex emergency fact sheet \#1(FY16). USAID. Retrieved from www.usaid.gov/crisis/syria/fy16/ fs 01 .

40. US Department of State (n.d.). State sponsors of terrorism. US Department of State. Retrieved from www.state.gov/s/ct/c14151.htm.

41. Wezeman, P. D. (2013). Arms transfer to Syria. SIPRI. Retrieved from www.sipri.org/ yearbook/2013/05.

42. Worldatlas. (2015, October 2). Where is Syria? Worldatlas. Retrieved from www.world atlas.com/as/sy/where-is-syria.html

43. World Bank. (2017, July 10). The visible impacts of the Syrian war may only be the tip of the iceberg. World Bank. Retrieved from www.worldbank.org/en/news/pressrelease/2017/07/18/the-visible-impacts-of-the-syrian-war-may-only-be-the-tip-ofthe-iceberg. 
44. Worldmark Encyclopedia of Nations. (2007). Syrian Arab Republic. Worldmark Encyclopedia of Nations. Retrieved from www.encyclopedia.com/places/asia/syrian-politi cal-geography/syria.

45. Yan, H. (2013, August 30). Syria allies: Why Russia, Iran and China are standing by the regime. CNN. Retrieved from http://edition.cnn.com/2013/08/29/world/meast/ syria-iran-china-russia-supporters/. 